\title{
PREVALENCE OF IRREGULAR RED CELL ANTIBODIES IN HEALTHY BLOOD DONORS ATTENDING A TERTIARY CARE HOSPITAL IN SOUTH INDIA
}

\section{Transfusion Medicine}

Keerthi C

Arun Rajendran*

Suresh Babu B

Praveen D

Sandhya G

Ravikanth C
Junior Resident, Department of Transfusion Medicine, Sri Venkateswara Institute of Medical Sciences, Tirupati

Associate Professor, Department of Transfusion Medicine, Sri Venkateswara Institute of Medical Sciences, Tirupati * Corresponding author

Assistant Professor, Department of Transfusion Medicine, Sri Venkateswara Institute of Medical Sciences, Tirupati

Assistant Professor, Department of Transfusion Medicine, Government Medical College, Cuddapah

Junior Resident, Department of Transfusion Medicine, Sri Venkateswara Institute of Medical Sciences, Tirupati

Junior Resident, Department of Transfusion Medicine, Sri Venkateswara Institute of Medical Sciences, Tirupati

Professor and Head, Department of Transfusion Medicine, Sri Venkateswara Institute of Medical Sciences, Tirupati

Sreedhar Babu KV

\section{ABSTRACT}

Introduction: Red cell antibodies that are found normally in human serum are considered naturally occurring and those are anti A and anti B. All other antibodies directed against RBC antigens are considered "unexpected or irregular".

Aim: This study is aimed to evaluate the prevalence of the anti-red blood cell antibodies among healthy blood donors.

Material and Methods: Antibody screening and identification was done using commercially available 3 cell and 11 cell reagent cells $(0.8 \%$ Surgiscreen, Ortho Clinical Diagnostics Limited, USA and Low ionic Strength Saline Ortho Bliss with AHG Cassettes) in antihuman globulin phase.

Results: A total of 36,684 donors were screened for the presence of irregular erythrocyte antibodies. Among these donors, twenty donors showed presence of alloantibodies in their serum $(0.054 \%)$. Most frequent alloantibodies identified were from Lewis blood group system. The results showed statistically a higher prevalence of RBC alloantibodies in males than in females.

Conclusion: Screening for presence of alloantibodies in donor blood is important to provide compatible blood products and to avoid transfusion reactions.

\section{KEYWORDS}

\section{alloantibody, donor screening, donation}

\section{INTRODUCTION}

Red cell antibodies anti $-\mathrm{A}$ and anti $-\mathrm{B}$ are the naturally occurring antibodies that are found normally in human serum. All other antibodies directed against RBC antigens are considered "unexpected or irregular". The national blood policy, 2007 has laid down the guidelines for the screening of donated blood for the presence of irregular red cell antibodies (1). Antibody screening in blood donors is done to avoid adverse transfusion reactions in recipients of plasma transfusion like immune hemolysis which can occur in patients for whom large amount of plasma is transfused or in paediatric patients. Alloantibodies have been detected in up to $0.8 \%$ of blood donors, $2-9 \%$ patients with a history of blood transfusion and $9-30 \%$ in patients who receive chronic transfusion therapy like sickle cell anemia, beta thalassemia, or hematologic malignancies (2-4). For safe and compatible blood transfusion, testing for irregular antibodies in blood donors should be performed. Since there is a paucity of literature on the prevalence of irregular red cell antibodies in blood donors, the present study was undertaken at a tertiary care hospital based blood bank in South India.

\section{MATERIALAND METHODS}

This is a retrospective observational study done in the department of transfusion medicine at Sri Venkateswara institute of medical sciences, Tirupati from January 2017 to January 2020. As per the departmental standard operating procedure (SOP), $4 \mathrm{ml}$ of EDTA blood were collected from the donor during blood donation for blood grouping and antibody screening. Blood grouping and antibody screening were performed on fully automated immune hematology platform (Ortho Auto Vue system, Ortho Clinical Diagnostics limited, USA) using column agglutination technology.

Antibody screening and identification was done using commercially available 3 cell and 11 cell reagent cells $(0.8 \%$ Surgiscreen, Ortho Clinical Diagnostics Limited, USA and low ionic Strength Saline Ortho Bliss with AHG Cassettes) in antihuman globulin phase.
All demographic details and significant clinical history were collected. The data were retrieved and entered into Microsoft excel sheet and analysis was performed with SPSS software version 21.0 (SPSS, Inc., Chicago, IL)

\section{RESULTS}

A total number of 36,684 donors donated their blood at our blood bank during the study period. Among the study population, antibody screening was positive in $20(0.054 \%)$ donors.

Among these 20 donors, 7 (35\%) were O group, 3(15\%) were A group, $4(20 \%)$ were B group and $2(10 \%)$ were AB group and $4(20 \%)$ were Bombay phenotype. Rh D positives were $95 \%$ and negatives were $5 \%$ (table 1). All were males and none of the females had irregular antibody (table 2).

Table 1 Blood group wise distribution of antibodies

\begin{tabular}{|l|ll|}
\hline Blood group $\mathbf{n}=\mathbf{2 0}$ & Number & $\mathbf{( \% )}$ \\
\hline $\mathrm{O}$ & 7 & $(35)$ \\
\hline $\mathrm{A}$ & 3 & $(15)$ \\
\hline B & 4 & $(20)$ \\
\hline AB & 2 & $(10)$ \\
\hline Bombay & 4 & $(20)$ \\
\hline Total & 20 & $(100)$ \\
\hline Rh-D positive & 19 & $(95)$ \\
\hline Rh-D negative & 1 & $(5)$ \\
\hline Total & 20 & $(100)$ \\
\hline
\end{tabular}

Table 2 Gender wise distribution of antibodies

\begin{tabular}{|l|ll|l|}
\hline Sex & Number & $\mathbf{( \% )}$ & Antibody positive (\%) \\
\hline Males & 36437 & $(99.3)$ & $20(100)$ \\
\hline Females & 247 & $(0.7)$ & 0 \\
\hline Total & 36684 & $(100)$ & $20(100)$ \\
\hline
\end{tabular}


In our study most common age group with positive antibody screen was found in 21-30 years followed by $18-20$ years (table 3 ).

Table 3 Donors age wise with positive antibody screen

\begin{tabular}{|l|l|}
\hline Age & Number (\%) \\
\hline $18-20$ & $6(30)$ \\
\hline $21-30$ & $7(35)$ \\
\hline $31-40$ & $2(10)$ \\
\hline $41-50$ & $5(25)$ \\
\hline Total & $20(100)$ \\
\hline
\end{tabular}

In the present study, the most frequent alloantibodies identified were from Lewis blood group system followed by the Bombay, MNS and Rh systems (table 4). The frequency of antibodies of Lewis blood group system in our study was found to be $35 \%(n=7)$. The frequency of antibodies of Bombay blood group system in our study was found to be $20 \%(n=4)$. The frequency of antibodies of MNS blood group system in our study was found to be $20 \%$ with anti M 5\% (1) and anti N $15 \%$ $(n=3)$. We have seen 1 panreactive antibody positive with all the reagent cell panels and one inconclusive antibody.

Table 4 Specificity of irregular antibody

\begin{tabular}{|l|lc|}
\hline Antibody specificity & \multicolumn{2}{|l|}{ Number $\%$} \\
\hline Anti Le & 7 & $(35)$ \\
\hline Anti H & 4 & $(20)$ \\
\hline Anti D & 3 & $(15)$ \\
\hline Anti M & 1 & $(5)$ \\
\hline Anti N & 3 & $(15)$ \\
\hline Inconclusive & 1 & $(5)$ \\
\hline Panreactive & 1 & $(5)$ \\
\hline Total & 20 & $(100)$ \\
\hline
\end{tabular}

\section{DISCUSSION}

Proper screening and identification of irregular red cell antibodies is important for selection of appropriate blood for transfusion, investigation of transfusion reaction, haemolytic anemia, haemolytic disease of newborn and serological changes in antenatal period. Atypical antibodies of system other than $\mathrm{ABO}$, reactive at $37^{\circ} \mathrm{C}$, are serologically significant and may result in decreased survival of donor red cell or haemolytic transfusion reaction in the recipient. Identification of alloimmunization will facilitate safe transfusion. The overall frequency of alloimmunization among healthy donors in our study was $0.054 \%$. Another similar study conducted in Delhi reported the presence of alloantibodies in sera of $0.05 \%(n=4 / 7756)$ donors (5).

In normal healthy individuals, anti-A and anti-B are generally the only RBC antibodies expected to be found in serum. All other antibodies directed against red cells are unexpected and are acquired through transfusion or pregnancy. They are known to occur in general population as well. Factors influencing the immunization rate and distribution of RBC alloantibodies include age, gender, and ethnicity, number of transfusions, autoimmune disease, immunoglobulin level, lymphoproliferative disease, solid malignancy and amount of incompatible erythrocytes received by the individual through transfusion (4). Proper detection and identification of unexpected or irregular alloantibodies in donors are important for smooth and safer transfusion to patients. The prevalence of such irregular red cell antibodies has been extensively studied in patients in various parts of the world and also in India, but the data regarding exclusive donor population are very limited.

The Lewis blood group system is different from other blood group systems, as the antigens $\left(\mathrm{Le}^{\mathrm{a}}\right.$ and $\left.\mathrm{Le}^{\mathrm{b}}\right)$ are formed in the plasma and absorbed onto the red cell membrane. Transfused red cells absorb Lewis antigens from the plasma of the recipient and within several days of the transfusion the phenotype of the circulating transfused red cells is the same as the patient's red cell phenotype. Antibodies specific for Lewis antigens are naturally occurring and usually IgM, complement activating, and reactive at or below room temperature. Lewis antibodies may be clinically relevant if the antibody causes in vitro haemolysis during serologic laboratory testing and antigennegative blood should be selected for transfusion. Lewis antibodies do not cause HDFN because they are IgM and do not cross the placenta and are poorly developed on fetal red cells. Anti-Le antibody is more common than anti-Le antibody (6). This is in contrast to our study where anti-Le $\mathrm{e}^{\mathrm{b}}$ antibody (35\%) was only identified.

$\mathrm{M}$ and $\mathrm{N}$ antigens are some of the oldest blood group antigens known after the $\mathrm{ABO}$ system. $\mathrm{M}+\mathrm{N}+$ cells are the most common genotype ( $50 \%$ of population). Anti-M and anti-N antibodies are usually IgM and are rarely associated with transfusion reactions. Antibodies to antigens in the MNS blood group system are often naturally occurring and if they do not react at $37^{\circ} \mathrm{C}$, can be ignored in transfusion practice. Rare examples of anti-M and anti-N have been reported to cause immediate and delayed haemolytic transfusion reactions and haemolytic disease of the fetus and newborn (HDFN). In our study anti-M was identified in one donor ( $5 \%$ ) and anti- $\mathrm{N}$ in $3(15 \%)$ donors. In a study done by Makroo et al, anti-M $-56.6 \%$ was identified and no one had anti-N (7).

Several studies have reported that the prevalence of irregular antibody in blood donors varies from $0.32 \%$ to $2.4 \%(8-12)$. The prevalence noted in the present study is $0.054 \%$, which is very less when compared to other studies. This large variation may be due to the different screening method used and characteristics of the population studied.

In our study, only males had irregular antibodies. This is in concordant with Makroo et al (7) and Pahuja et al (5) where males had a higher prevalence.

A study carried out on erythrocyte alloantibody specificity on the population of Olmsted County, Minnesota by Winter et al. (4) in 2001 reported $0.89 \%$ prevalence among blood donors. They included transfusion recipients, donors, and pregnant women in their study, which probably explains the higher percentage of isoimmune erythrocyte antibodies.

Ameen et al. in 2005 reported $0.49 \%$ prevalence of alloantibodies in Kuwaiti general population, whereas incidence in blood donors was $2.3 \%(10)$. They also noted that frequency of alloantibodies was greater in Kuwaiti females as compared with males (three times higher in female) which was in contrast to our study where males had higher prevalence of antibodies compared to females.

Mollison et al. also stressed that chances of haemolytic reactions due to the presence of irregular erythrocyte alloantibodies in the donor's plasma other than anti-A and anti-B are very rare. Screening of the donor's plasma is a relatively simple test and capable of detecting potent antibodies to the clinically significant antigens (13).

\section{CONCLUSION}

This study highlights the significance of detecting irregular erythrocyte antibodies in healthy donors. Screening for presence of alloantibodies in donor blood is important to provide compatible blood components and to avoid transfusion reactions. Screening donor sera for antibodies serves to simplify the work of cross-matching by eliminating the need for the minor crossmatch. Since there was a presence of inconclusive antibodies in the present study, we may have to consider indigenous cell panels for better results. However, largescale studies are required to assess the magnitude of irregular antibodies in blood donors and to assess the clinical significance of the same.

\section{REFERENCES}

1. National Blood Policy (National Aids Control Organization, NACO), Ministry o Health \& Family Welfare; 2007

2. Hamilton JR. Common and frequently encountered antibodies. Transfus Apher Sci 2009;40:189-94.

3. Hoeltge GA, Domen RE, Rybicki LA, Schaffer PA. Multiple red cell transfusions and alloimmunization. Experience with 6,996 antibodies detected in a total of 159,262 patients from 1985 to 1993 . Arch Pathol Lab Med 1995;119:42-5.

4. Winters JL, Pineda AA, Gorden LD, Bryant SC, Melton 3rd LJ, Vamvakas EC, et al. RBC alloantibody specificity and antigen potency in Olmsted County, Minnesota. Transfusion 2001;41:1413-20

5. Pahuja S, Kushwaha S, Sethi N, Pujani M, Jain M. Screening of blood donors fo Pahuja S, Kushwaha S, Sethi N, Pujani M, Jain M. S
erythrocyte alloantibodies. Haematology 2012;17:302-5

6. Webert Kathryn E, Smith James W, Arnold Donald M, Chan Howard HW, Heddle Nancy M, Kelton John G. Red cell, platelet, and white cell antigens, wintrobe's clinica haematology. 12th ed. Lippincott Williams \& Wilkins; 2009.

7. Makroo RN, Rajput S, Agarwal S, Chowdhry M, Prakash B, Karna P. Prevalence of irregular red cell antibody in healthy blood donors attending a tertiary care hospital in North India. Asian J Transfus Sci. 2018;12:17-20.

8. Myhre BA, Greenwalt TJ, Gajewski M. Incidence of irregular antibodies occurring in healthy dons

Giblett ER. Blood group alloantibodies: an assessment of some laboratory practices. Transfusion. 1977;17:299-308.

10. Ameen R, Eyaadi OA, Shemmari SA, Chowdhury R, BashirAA. Frequency of red blood cell alloantibody in Kuwaiti population. Med Princ Pract. 2005;14:230 - 4

11. Zhu JY, Lan JC, Luo HQ. Screening analysis of irregular antibodies from random dono population in Shaoguan area. J Exp Haematol. 2007; 15:630-1.

12. Tormey CA, Fisk J, Stack G. RBC alloantibody frequency, specificity and properties in population of male military veterans. Transfusion. 2008;48:2069-76.

13. Mollison PL, Engelfriet CP, Contreras M. Blood transfusion in clinical medicine. 11th edn. Philadelphia: F.A. Davis Co.; 2005. p. 328 